\title{
The Spectacle of Justice in the Roman Empire
}

\author{
Margherita Carucci
}

\section{Introduction}

In a wealthy house of El Djem, in Roman Africa, a late 2nd century-early 3rd century C.E. floor mosaic illustrates the spectacles of the amphitheatre (fig. 12.1). ${ }^{1}$ The heavily damaged panel shows a platform or scaffold in the centre and beasts (bears and leopards) distributed along the sides; the two surviving corners include representations of men being delivered up to a wild beast: one is pushed by a handler, his face being devoured by a leopard, which has planted its claws in the victim's thighs; the other is held by two handlers, while a leopard is ready to attack him; blood streams from their wounds and forms paddles beneath them similar to other pools of blood irregularly covering the surface of the arena. These two scenes are a clear illustration of the damnatio ad bestias, that is, the condemnation of criminals to wild beasts as a form of capital punishment, which was performed during the games of the amphitheatre. Laid out in a reception room for being seen by a number of guests, the whole mosaic probably served to celebrate the munificence and the wealth of the house-owner, who paid for the games and offered spectacular entertainment as a munus including the punishment of criminals. However, inserted within the wider framework of Roman ideology and values, this figurative mosaic is also a clear illustration of the workings of penal justice in the Roman Empire.

Throughout human history, public executions of criminals have been carried out in a variety of modes as an expression of changing mentalities. Rome, however, remains extraordinary for the scale and method of its violence, for the systematic punishment and destruction of convicted criminals, and for its exuberance. ${ }^{2}$ The arrangement of spectacular shows that the whole population was invited to attend, the intentional and orchestrated killing of criminals

1 M. Carucci, The Romano-African Domus. Studies in Space, Decoration, and Function (Oxford 2007), 57, 148-150.

2 For a more detailed discussion on the exuberance of Roman executions, see J.-J. Aubert and A.J.B. Sirks (eds.), Speculum iuris. Roman Law as a Reflection of Social and Economic Life in Antiquity (Ann Arbor 2002). 


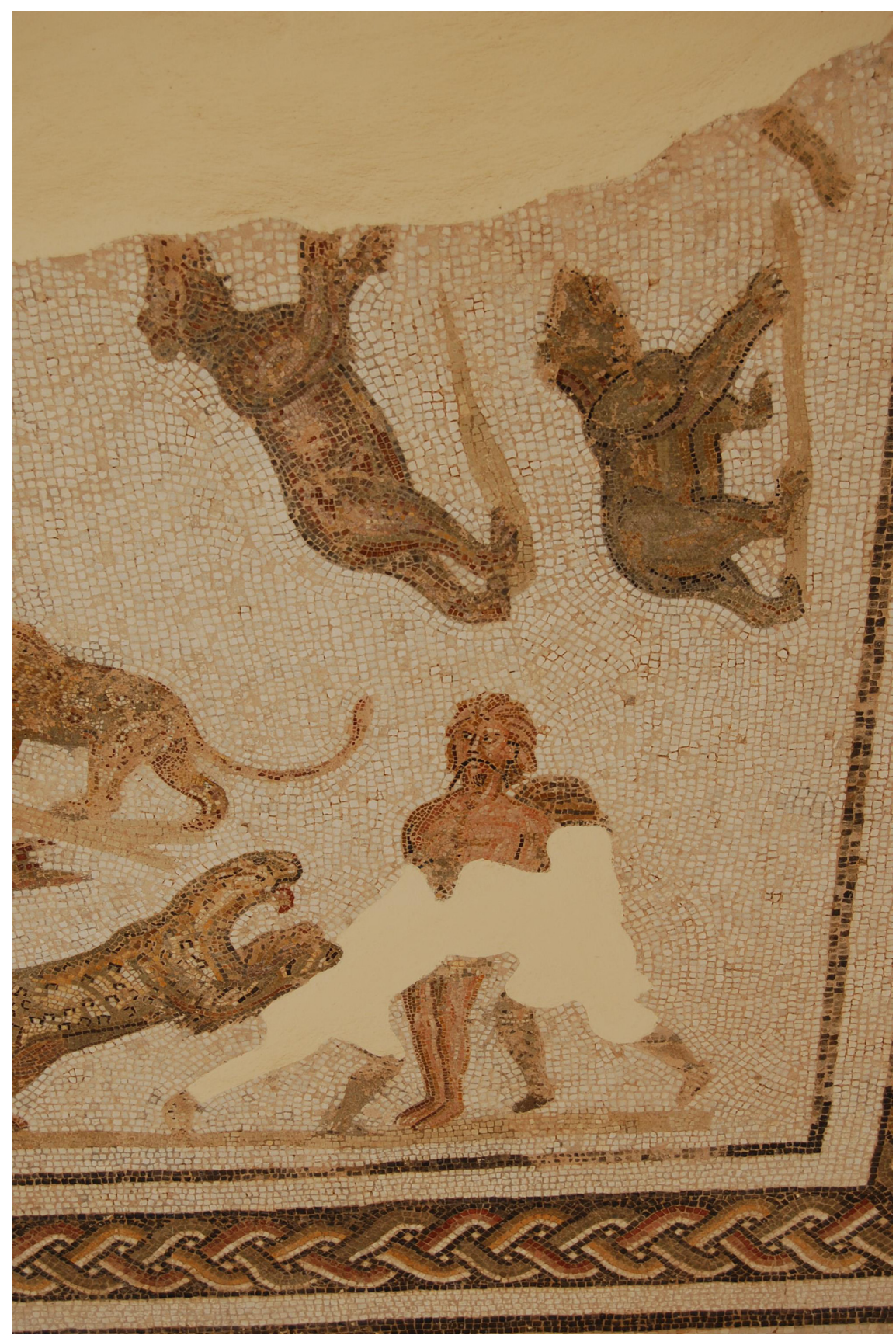

FIGURE 12.1A El Jem, Sollertian Domus, mosaic of amphitheatre scenes: at corners scenes of damnati ad bestias devoured by leopards 
by the state in public areas and occasions for entertainment, the adoption of torture methods designed to prolong severe physical pain till death, and the performance of ritualised and even mythologised executions make the public executions distinctly Roman. No pre-modern culture seems to rival ancient Romans in the extent and duration of their institutional murder. The deadly games in Roman society have been widely discussed by modern scholars, who have used a number of theories or models to explore origins, nature, and function of Roman shows. Some scholars highlight the religious roots and overtones of the early games, which retained their cultic significance in imperial times; ${ }^{3}$ others link the games to Roman militarism or imperial politics; ${ }^{4}$ social, moral, and psychological interpretations are also offered to explain the arena's excessive violence. ${ }^{5}$ However, an aspect of the Roman shows that has not been fully explored in modern scholarship is the conceptual link between the execution of convicted criminals in the public area of the amphitheatre and the imperial notion of justice. For the summa supplicia as staged during the shows in the arena were aggravated and ultimate punishments inflicted on wrong-doers for their crimes in front of their community. ${ }^{6}$

The inclusion of capital punishments within the ludic setting of the arena shows is a further element that makes public executions distinctly Roman: convicted criminals were brought into the amphitheatre and killed in front of the audience as part of a programme including gladiatorial fights, exhibitions of animals, and the slaughter of wild beasts. Charting the typical arena spectacle is a difficult task, since the ancient sources are scattered. The standard 'classical' form of munus with morning venationes, lunchtime executions, and afternoon gladiatorial combats is a modern reconstruction that is not supported by ancient textual sources. Literary evidence, on the contrary, attests a great variety in the types and combinations of events, which makes it difficult to ascertain that public executions were always performed at lunchtime or along with venationes and gladiatorial fights in the same munus. ${ }^{7}$ What ancient evidence seems to allow us to confirm on more secure grounds is that with the urban development of Roman society, punishment became a matter of pub-

3 A. Piganiol, Recherches sur les jeux romains (Strasbourg 1923).

4 K. Hopkins, Death and Renewal. Sociological Studies in Roman History II (Cambridge 1983).

5 P. Plass, The Game of Death in Ancient Rome. Arena Sport and Political Suicide (Madison 1995); G.G. Fagan, The Lure of the Arena: Social Psychology and the Crowd at the Roman Games (Cambridge 2011).

6 E. Cantarella, I supplizi capitali. Origine e funzioni delle pene di morte in Grecia e a Roma (Milano 2005).

7 G. Ville, La gladiature en Occident des origines à la mort de Domitien (Rome 2014), 386-430. 
lic display. ${ }^{8}$ Crosses along the roads leading into major centres and parades of delatores in the amphitheatre are just a few examples of Roman attitude toward the publicity of physical chastisement. ${ }^{9}$ Accordingly, the shows of the amphitheatre, with their emphasis on body and pain, became the most convenient venue for the performance of corporeal punishments in full view before a massed large audience. However, the variety of the events included in the shows warns us from searching for a common theme or aim. I find it difficult to see the performance of Roman justice in the fights against wild beasts or in the gladiators' combats, while this is more evident in the punishment of wrong-doers. Rather, it was the particular combination or isolation of the events during the shows that gave munera a distinct potency and forced spectators to confront some fundamental themes of Roman culture (e.g. the extent of Roman power in the exhibition and killing of exotic beasts, the skills and bravery of gladiators and venatores, the centrality of military activity). In the case of summa supplicia, the most important value that the audience was asked to celebrate was justice.

The concept of justice as visualised in the performance of the deadly games challenges us to confront a number of questions that our modern ideal of state executions to be carried out with discretion prompts when dealing with ancient summa supplicia: How did the spectacular killing of condemned criminals convey ideas of justice and fairness? How was capital punishment associated with the Roman value of iustitia? How did ancient Romans use violence and death to practice the law? A full and satisfactory answer to these questions will prove to be extremely difficult, since the Romans said very little explicitly about the notions of justice and capital punishment in relation to public shows.

A few references can be found in the Corpus Iuris Civilis. Although the legal material compiled in the Digest has been excerpted, arranged, and sometimes updated by the compilers, it still provides useful insights into the practice of criminal law in earlier imperial times. The brevity of the legal sources may be completed by the narrative sources, which supply a window on public opinion and attitudes toward spectacular killing and justice with either their detailed accounts of public executions in the amphitheatre or brief references to them. However, literary record has some limitations. Ancient writers, belonging to the elite class of the Roman Empire, were not especially interested in writing

8 For the evolution of capital punishments from domestic to public, see Cantarella 2005, op. cit. (n. 6).

9 K.M. Coleman, '“Informers" on parade', in B. Bergmann and C. Kondoleon (eds.), The Art of Ancient Spectacle (New Haven and London 1999), 231-245. 
about summa supplicia in the arena. When they report facts about shows and capital executions, they tend to focus on those details that revealed something about the emperor's personality or could be used as an opportunity for wider considerations on values and principles of conduct. The gladiatorial combats, for example, were often described by the educated elite as a lesson of courage and bravery exciting the noblest sentiments, such as love of glory and scorn of death. The executions of low-status criminals, by contrast, were seen as a sign of moral degradation and a manifestation of vulgarity typical of bloodthirsty masses from which the elite should keep some distance. ${ }^{10}$ However, the ancient elite authors rarely go beyond what seem mere generalisations taken from a stock pile of 'philosophical' commonplaces. The inclusion of public executions in the shows of the arena throughout the imperial times attests their popularity among the larger masses.

Unlike the pagan sources, Christian writings contain a large number of documented traditions about Christians executed during the pagan games in the arena. However, since their main aim was to celebrate the heroism of saints and martyrs, who endured any sort of atrocities and physical abuse by cruel pagans without losing their faith, Christian authors end up creating a one-dimensional approach toward Roman justice.

The limited historical perspective of both legal and literary sources can be enhanced by the use of archaeological and iconographical evidence. In fact, artistic representations of executions in the shows, along with the physical remains of Roman amphitheatres, where the shows were held, may help widen the interpretative framework of a discourse on Roman justice and spectacular killing by reminding us of an important element that is not often fully considered: watching criminals being executed in the arena, as well as viewing them represented on a floor mosaic, was fundamentally a visual experience. ${ }^{11}$

The discussion of the mosaic representations of summa supplicia will serve to fill the gap of textual record and to highlight the visuality of executions, the experience of the audience as viewers, and the concept of justice as performance. The mosaics will be discussed just as a starting point for wider considerations on Roman idea of justice and will be complemented by tex-

\footnotetext{
10 See, for example, Seneca, Ep. 7.2.

11 The use of the notion of visuality as an interpretative framework for discussing spectacular killing is drawn upon a number of publications exploring Roman ways of seeing, e.g. J. Elsner, Art and the Roman Viewer. The Transformation of Art from the Pagan World to Christianity (New York 1995); R. Nelson (ed.), Visuality Before and Beyond the Renaissance (Cambridge 200o); D. Fredrick (ed.), The Roman Gaze. Vision, Power, and the Body (Baltimore and London 2002).
} 
tual record and archaeological evidence for the structural arrangement of the Roman amphitheatre.

The view of wrong-doers being punished for their offences, of the seating arrangement in the amphitheatre, whereby spectators were allocated to specific areas according to their social rank, and of the spectators participating in the shows with their vocal expressions and emotional reactions turned the abstract concept of justice into something tangible and visible for the audience to understand and reproduce. To demonstrate this, I will discuss some RomanoAfrican mosaics illustrating capital executions in the arena ${ }^{12}$ and some relevant passages in ancient writings as the basis for exploring the concept of Roman justice in the early and mid-imperial times. I will then suggest that for ancient Romans summa supplicia in the arena were not brutal forms of entertainment for bloodthirsty audiences. They were, rather, a powerful means for visualising the workings of imperial justice as a sign to see, a value to share, and a performance to play with the ultimate goal of restoring and reaffirming the established order. As a starting point, I will go back to the El Djem mosaic mentioned above, since this mosaic is a clear illustration of the main points of my discussion: spectacular killing, the notion of justice, the role of the audience, and visual impact.

To the modern viewer the El Djem mosaic, with its representation of spectacular killing to be displayed in a house for its owner's guests, may appear somewhat disturbing and distasteful when viewed through our ideological lenses. However, placing this mosaic within the context of Roman society and ideology may help us to understand Roman attitudes towards institutionalised violence and justice.

The shows of the amphitheatre were a popular subject of Roman art. ${ }^{13}$ Scenes of wild beasts, hunters, and gladiators illustrated either as inactive or in combat formed a stock repertoire that was widely used in domestic art for

\footnotetext{
12 To my knowledge, these mosaics are the only surviving examples of artistic representations of summa supplicia in the arena.

13 For the analysis of Roman mosaics illustrating summa supplicia, see K.M.D. Dunbabin, The Mosaics of Roman North Africa. Studies in Iconography and Patronage (Oxford 1978), 65-87; S. Brown, 'Death as decoration: scenes from the arena in Roman domestic mosaics' in A. Richlin (ed.), Pornography and Representation in Greece and Rome (New York 1992), $180-211$.
} 
evoking the games of the amphitheatre whose main events were combats of gladiators, hunting of wild beasts (venatio) by skilled hunters (venatores) or less well-trained fighters (bestiarii), and executions of wrong-doers (summa supplicia). Whereas gladiatorial combats, venationes, and display of wild beasts were the most-illustrated amphitheatre scenes on mosaics across the Empire, the owner of the Sollertiana Domus at El Djem chose a less popular subject for decorating his reception room: the executions of criminals condemned to wild beasts. Though the figures of the wild beasts are taken from the standard decorative repertory, the scenes of execution in the surviving corners seem to evoke a particularly memorable incident that may have occurred during the games offered by the house-owner. For the representation of damnati ad bestias, the mosaicist used specific details, such as shaggy hair, reddish-skin, and the fringed loincloth as their own peace of garment, that may not have been intended for a portrait, but clearly characterise these figures as non-Romans. The characterisation of the convicted criminals as barbarians served to highlight the cultural and social distance between the Roman viewers and the barbarian criminals and to create some kind of moral barrier that blocked the viewer's empathy with the victims represented on the mosaic.

The opposition between Roman and barbarian, innocence and guilty, safe and exposed is more evident in another floor mosaic (fig. 12.2), which decorated the room of a villa at Zliten, in modern Libya. Dated to the late ist century C.E., the well-preserved mosaic illustrates the various events of an entire munus on a narrow frieze running along the central portion of the floor: fights of different types of gladiator, venationes and combats of wild beasts, musicians, and executions of criminals. In one corner a man tied to a stake is mauled by a leopard clinging to his chest; at his back another criminal is tied to a stake on a movable cart that two attendants are manoeuvring with long handles towards a big cat. A third scene shows a man being gripped by the hair and propelled towards a lion by an attendant who has a whip in his other hand. Salvatore Aurigemma identifies the damnatiad bestias as the Garamantes (inhabitants of the area around Tripoli), who were captured during the incursion into the area of Leptis Magna in 70 C.E., as Tacitus reports in his Historiae (4.50): the whole mosaic would record the games held in celebration of the Garamentes' defeat on that occasion. ${ }^{14}$ Though it is difficult to ascertain whether the Zliten mosaic records this particular encounter, ${ }^{15}$ it is evident that the mosaicist intended to characterise the convicted criminals as barbarians. Their dark skin in con-

14 S. Aurigemma, Imosaici di Zliten (Roma 1926), 269-278.

15 Dunbabin 1978, op. cit. (n. 13), 235 . 


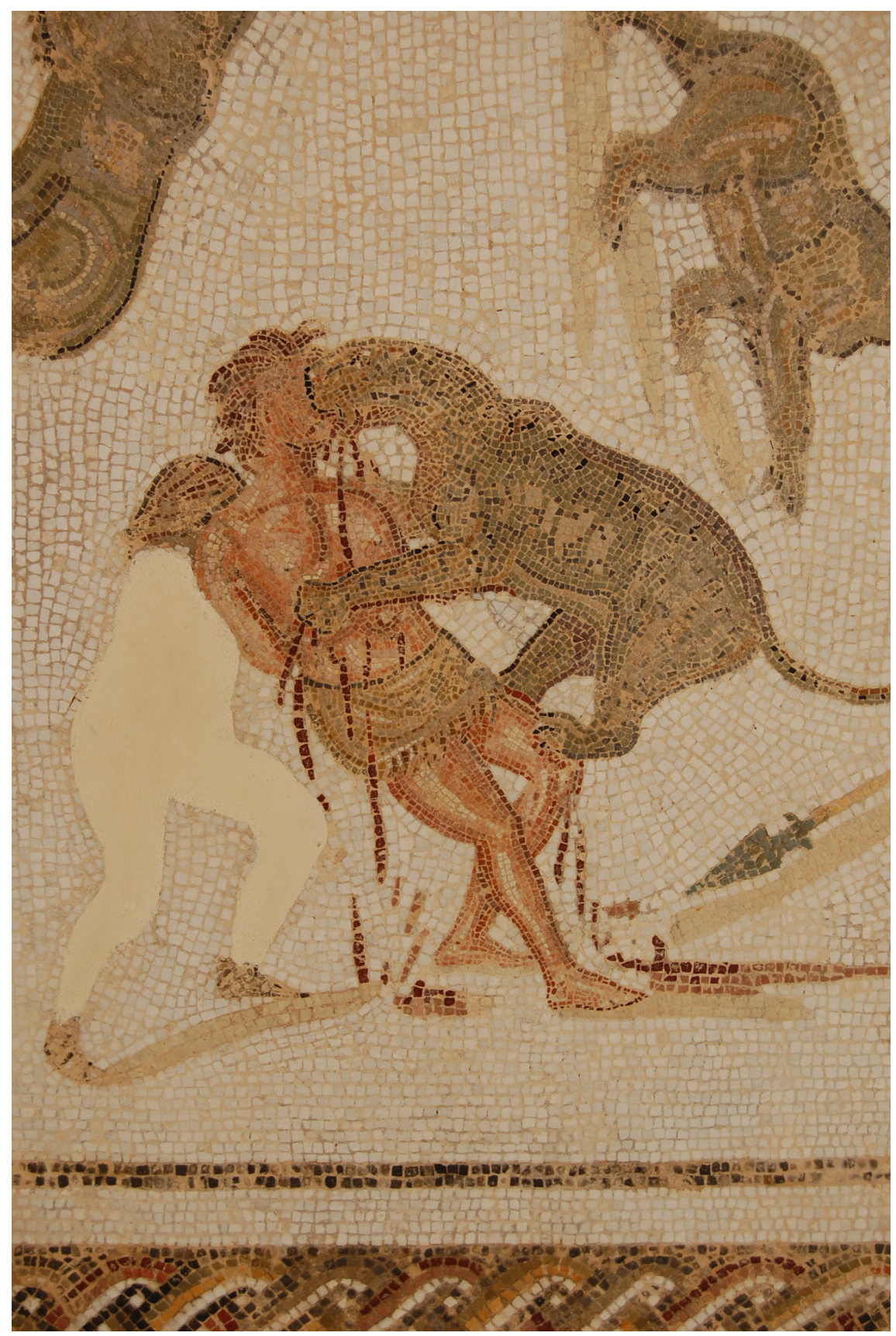

FIGURE 12.1B El Jem, Sollertiana Domus, mosaic of amphitheatre scenes: at corners scenes of damnati ad bestias being attacked by a leopard 


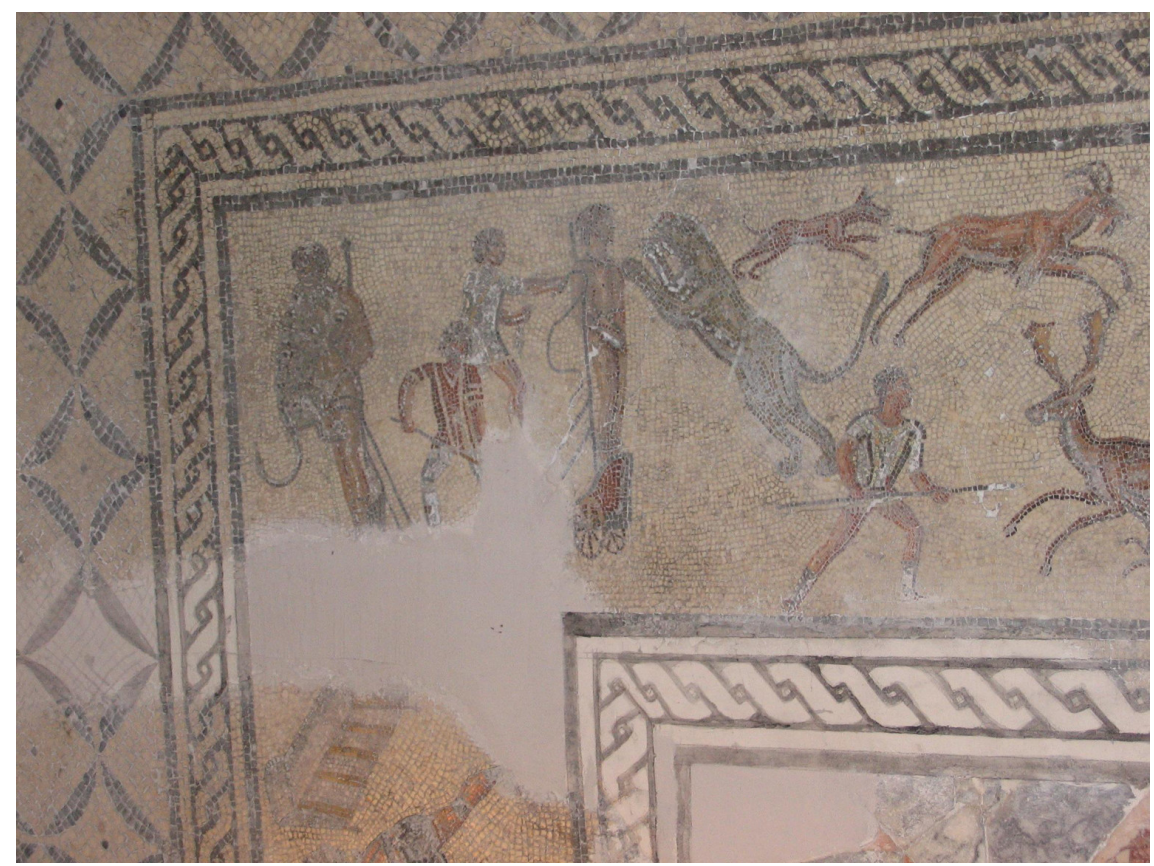

FIGURE 12.2A Zliten, Villa, mosaic of amphitheatre scenes: detail illustrating man tied to a stake and mauled by a leopard

trast to the pinkish-brown skin of the nearby gladiators and their passive position in contrast to the dynamic action of the surrounding figures (gladiators, venatores, and musicians, and indeed animals) visualise the social and moral distance between the Romans and the 'Other'. Ancient viewers of these two mosaics would have immediately recognised the convicted criminals as barbarian invaders who deserved to be subject to Roman justice for their attack against the Roman insiders. However, the representation of spectacular killing in the arena may have reminded the viewers of other types of criminals that were commonly executed during the shows in the amphitheatre for their being 'Other', not only barbarian outsiders but also home-grown criminals, that is, individuals who could not be integrated in the Roman social structures because they were did not accept and perform those values on which Roman morality and identity were.

These two Romano-African mosaics may leave us with the false impression that in Roman eyes only barbarians deserved to be executed through exposure to wild beasts during the games of the amphitheatre. Textual evidence shows that the victims of staged executions in public were drawn from all over the Empire: they included prisoners of wars, captured rebels, deserters, brigands, 


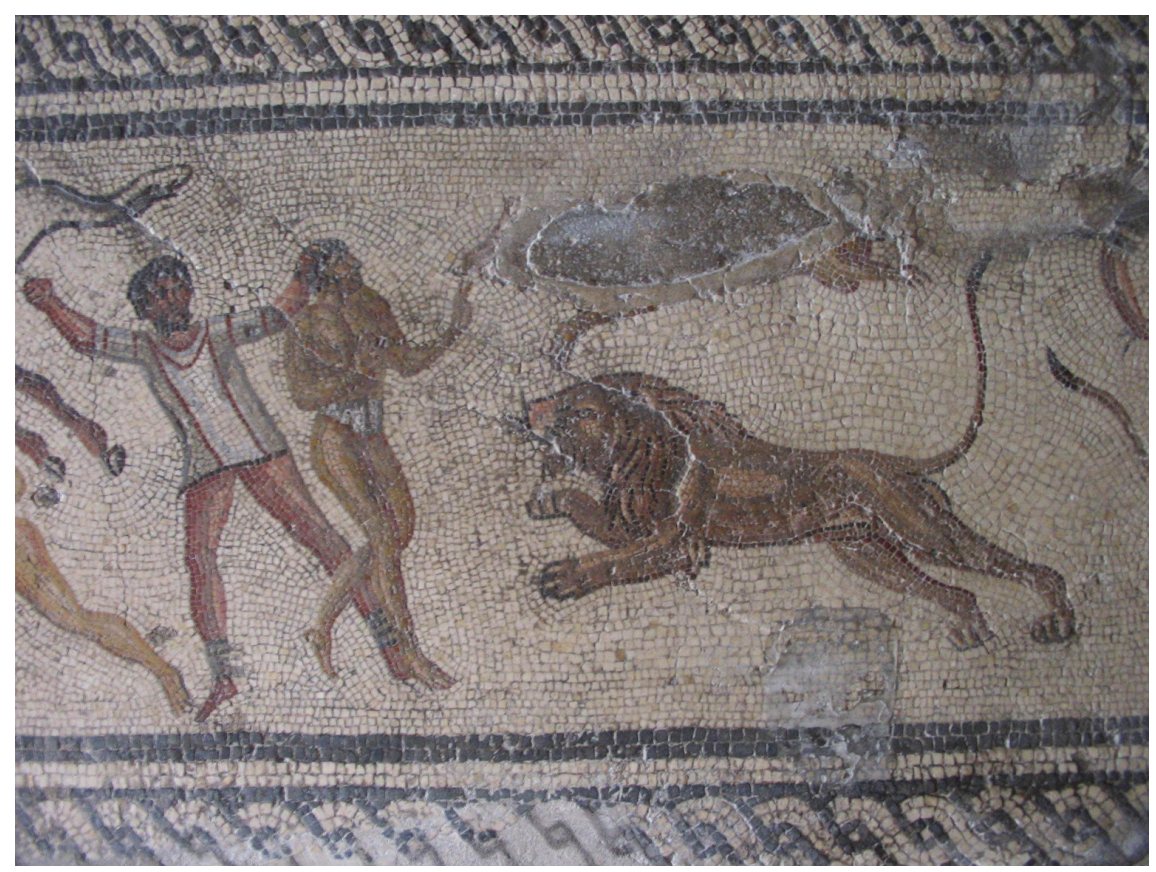

FIGURE 12.2B Zliten, Villa, mosaic of amphitheatre scenes: detail illustrating man pushed towards a lion

fugitive slaves, forgers, abductors, and murderers. ${ }^{16}$ However, the representation of the barbarian type was more visually accessible: the viewer was able to recognise the barbarian origin of the figure depicted on the mosaic from a few stock details and immediately read his execution as the just punishment that members of the rebellious barbaric tribes deserved. Moreover, the figure of the barbarian as the more immediately recognisable type of non-Roman served to assure the house-owner and his wealthy guests that capital executions in the public were reserved only to non-Romans or Romans of inferior rank. Roman modes of punishment, in fact, were a matter of social status.

16 For a list of textual references to damnati ad bestias in Roman imperial times see Ville 2014, op. cit. (n. 7), 236-237 note 21. 
In Roman social practices and codes of criminal law, the political semantics of punishment rested on a close correlation between status and penalty. ${ }^{17}$ In the Early Empire, penalties were meted out according to the criminal's legal status and social standing. A Roman citizen of high status and a non-citizen could be brought up on the same criminal charge and yet be punished differently: the former was exempt from the harsh penalties that were commonly inflicted upon the latter. Citizenship and social standing were the determinants of penal status. The differentiation in penalties according to the social status of the offender was maintained even when the granting of citizenship to all free persons throughout the Empire by the Constitutio Antoniniana of 212 C.E. made the distinction between Roman citizens and others obsolete. In the hierarchy of the criminals' rights, the Roman penal system continued distinguishing between honestiores (senators, soldiers and others in the emperor's service, members of municipal councils and their families) and humiliores (every free citizen of lower status). Honestiores retained traditional legal privileges, while the less fortunate rest of the population (humiliores) became subject to those aggravated forms of punishment to which non-citizens had been liable in the earlier centuries. In this dual penal system, protection from corporal punishment ceased to be the hallmark of Roman citizenship, as Ulpian clearly states in the Digest (48.19.28.2):

Non omnes fustibus caedi solent, sed hi dumtaxat qui liberi sunt et quidem tenuiores homines: honestiores vero fustibus non subiciuntur.

It is not customary for all persons to be whipped, but only men who are free and of lower rank; those of higher rank are not subjected to the penalty of castigation. ${ }^{18}$

Citizens of low status were left physically vulnerable by the law and liable to the harshest forms of capital punishment, that is, crucifixion, exposure to wild

17 P. Garnsey, Social Status and Legal Privileges in the Roman Empire (Oxford 1970); R.A. Bauman, Crime and Punishment in Ancient Rome (London and New York 1996), 124-140; J.J. Aubert, 'A double standard in Roman criminal law? The death penalty and social structure in Late Republican and Early Imperial Rome', in Aubert and Sirks 2002, op.cit. (no.2), 94-133.

18 All translations are my own. 
beasts (damnatio ad bestias), and burning alive (crematio), which had been traditionally reserved to slaves. In the traditionally hierarchical structure of the Roman society, the unequal treatment of people was a widely accepted customary behaviour that was never abandoned. In Epistula 9.5, Pliny the Younger praises his friend Calestius Tiro for the administration of justice in his province by preserving distinctions of class and rank:

Temperare mihi non possum, quominus laudem similis monenti, quod eum modum tenes, ut discrimina ordinum dignitatumque custodias; quae si confusa, turbata, permixta sunt, nihil est ipsa aequalitate inaequalius.

I cannot restrain myself from sounding as if I were proffering advice when I mean to praise you for the way you preserve the distinction of class and rank; if they are thrown in confusion and disorder and mixed up, nothing is more unequal than the same equality.

From the point of view of the elite class, to which Pliny and Caelestius Tiro belonged, social and juridical equality would have collapsed the traditional social hierarchy, in which people were classified by rank, and diminished the elite's entitlement to privileges and ranked penalties. ${ }^{19}$

The illustration of barbarian prisoners being punished with death on the Romano-African mosaics described above functions not just as a mirror image of the double standard of Roman criminal law but also as reassuring message to the commissioner and his influential guests that inequality before the law is guaranteed, while reminding domestic servants of the fatal consequences of their offences.

Transposed into the shows, where wrong-doers were executed in the presence of the whole community, this message was amplified. The physical destruction of convicted criminals in front of spectators of every social status showed in its powerful immediacy that justice and worthy inequality of the Roman social order were not mere concepts to contemplate but something that was actually exercised and expected. The summa supplicia were certainly a very evocative moment for the communication and performance of the established order, but the spectators too were expected to confirm, reinforce, and enact the inequality of social order and justice by sitting in specific areas of

19 See Cicero Rep., 1.43: "The same equality is unequal, when it does not recognise grades of dignity." 
the amphitheatre. The spectacle of justice started in the very beginning of the games, when spectators entered the amphitheatre and sat in well-defined areas of the building. ${ }^{20}$

When viewing the amphitheatre scenes illustrated on the mosaics, we cannot help noticing that the spectators are left out of the picture. The absence of spectators is quite remarkable, considering the enormous number of people that could be seated in buildings such as the amphitheatre at El Djem. The representation of the audience in the shows is rare, even in the mosaics illustrating other types of games, such as venationes and gladiatorial fights. When there is a presence of the audience, it is reduced to sketchy representations of a few men, like in the 3rd-century mosaic of a venatio from a house in Thelepte near Kasserine in North Africa. ${ }^{21}$ The two surviving panels show the heads and shoulders of ten male spectators (five in each panel) watching a venator in the act of transfixing a lion with his spear in the central scene below. It is difficult to ascertain the reason for the schematised representation of ordinary spectators, or for their total removal from the scenes of the amphitheatre games. Perhaps the mosaicist followed a set of artistic conventions; perhaps the inclusion of spectators would have reduced the space for the main subject of the floor mosaic, that is, the representation of the games and their performers; perhaps the individual patron did not want to include ordinary onlookers in the mosaic he was paying for. Wherever the reason may lie, the inclusion of a few onlookers in the mosaic or their total absence helped the viewer focus on the central action taking place and on its symbolic content.

In the floor mosaics from El Djem and Zliten, the artistic arrangement of the scene with the representation of damnati ad bestias in the corners invited the viewers to walk around the outer band of the mosaic in order to appreciate the figurative scenes facing outwards. In their physical presence, the viewers replaced the absent onlookers in the mosaic and re-enacted their role as spectators of the shows not just in their act of viewing the spectacle but also in

$20 \quad$ E. Rawson, 'Discrimina ordinum: the Lex Julia Theatralis', Papers of the British School at Rome 55 (1987), 83-114.

21 Dunbabin 1978, op. cit. (n. 13), 69-70; R. Lim, 'In the "Temple of Laughter": visual and literary representations of spectators at Roman games' in Bergmann and Kondoleon 1999, op.cit. (no.9), 343-365: 347 (the paper focuses on the representation of spectators in Late Antiquity). 
their location in the stands of an amphitheatre. In fact, the position of the viewers of the mosaic along the walls of the room and of the mosaic in the middle recalled the architectural arrangement of the amphitheatre with its seats for the spectators placed around the central area where the show was performed. The arrangement of the audience around the central area of the stage may appear as a simple architectural device for directing the spectators' gaze toward the same direction and helping them focus their attention toward the action taking place in the middle. However, in the hierarchical structure of Roman society, the precise geometry of the arena's architecture served also to reflect and reinforce the Roman social order (fig. 12.3). For the seating area of the amphitheatre was divided horizontally into several zones which were assigned to specific groups of spectators according to their social rank. The result was a clear division between the front rows reserved for the privileged members of Roman society, such as the emperor and his family, senators, and Vestals, and the back area for the mass of ordinary citizens and the poor. Specifically assigned seats were not the only means for emphasising the social division within the assembled crowd. Distinction of dress too visibly advertised social differences. ${ }^{22}$ When, for instance, Corydon went to Rome and attended a venatio staged in the wooden amphitheatre that Nero wanted erected in the Campus Martius in 57 C.E. ${ }^{23}$ the poor countryman had to sit where the dirty-cloaked mob usually watched, while the equites and tribunes down below were glowing in the sun in their white togas. ${ }^{24}$ Corydon, in Siculus' Eclogue, wishes that he had not been clad in peasant garments that prevented him from taking a more forward seat and getting a better view of the god-like emperor Nero, who was watching the show. ${ }^{25}$ The distribution of seats and dress code at Roman spectacles mirrored the social and juridical stratification of Roman society. As Corydon's experience as spectator of a show in Rome highlights, the segregation of the spectators into peer groups according to their social rank and visible dress singled out three main social groups: the emperor, the elite, and the rest of the population.

Yet, as a whole the audience formed a single group embodying the Roman good order, while the wrong-doers being killed in the central stage of the arena

22 J.C. Edmondson, 'Dynamic arenas: gladiatorial presentations in the city of Rome and the construction of Roman society during the Early Empire', in W.J. Slater (ed.), Roman Theater and Society. E. Togo Salmon Papers I (Ann Arbor 1996), 69-112: 84-86.

23 Tac. Ann. 13.31.1; Suet. Nero 12.1; Plin. HN 16.200.

24 Calpurnius Siculus, Ecloga, 7.26-29; G.B. Townend, 'Calpurnius Siculus and the Munus Neronis', Journal of Roman Studies 70 (1980), 166-174.

25 Calpurnius Siculus Ecloga, 7.79-84. 

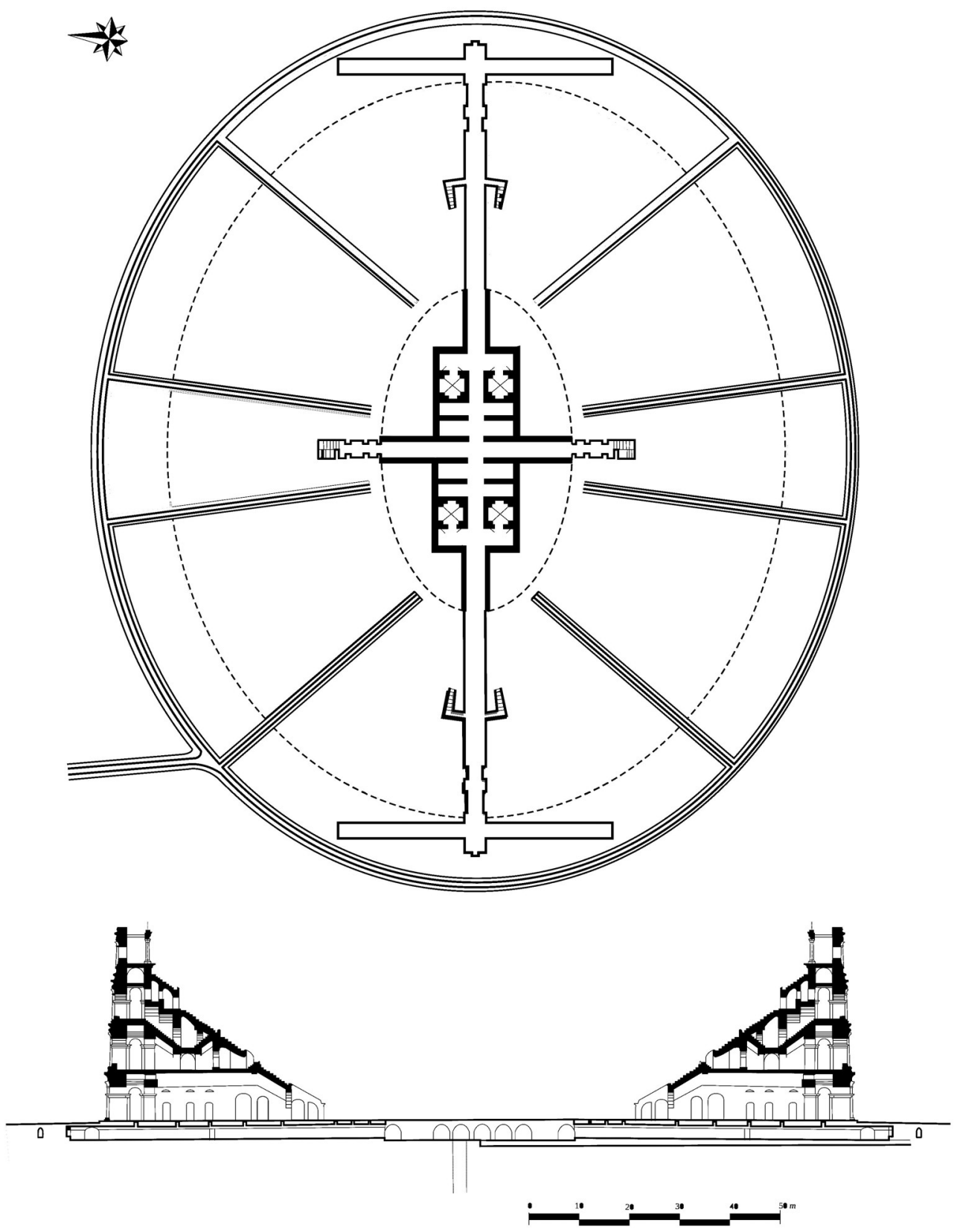

FIGURE 12.3 El Jem, Amphitheatre: ground plan 
represented the social outcasts whose offences had degraded and deprived them of their identity and position in the community. The result was a clearly visible opposition between two main groups: the good and innocent Us in the upper seating zones and the bad and guilty Other in the lower central area. The architectural layout prevented the audience from coming into contact with the convicted criminals but facilitated the imposition of an axial visibility on them as objects to be seen and violated: the right to a viewing invested the audience with the authority to impose their punitive and judgemental gaze upon the wrong-doers. However, visualising the physical and social opposition between these two groups was not the only means for reaffirming the established social order. The execution of convicted criminals was a show of death in which both criminals and audience had to play their role.

\section{5}

Playing Justice

In Roman eyes, the wrong-doers displayed in the shows of the amphitheatre were noxii, a term from the verb nocere ("to harm, injure") to describe those who have caused harm and are therefore liable to punishment. Being guilty, the noxii deserved to be humiliated through the disposal of their bodies. On some occasions, their physical humiliation and degradation was staged in the more spectacular form of what Kathleen Coleman describes as "fatal charades", that is, the execution of criminals staged as the enactment of a famous death of myth or legend. ${ }^{26}$ Visual record of these deadly dramas entailing real death on stage may be the floor mosaic of the Villa du Taureau at Silin, in modern Libya (fig. 12.4). ${ }^{27}$ The mosaic shows two small figures being tossed by a huge white bull, while a third one is pushed towards the animal by a man wearing an animal skin; another figure hands out a hooked staff towards the two figures in the air. Above the scene is an inscription, Filoserapis comp.

The identity of the damnati ad bestias represented on the Silin mosaic remains unknown. G.Ch. Picard identifies the victims as easterners for their specific costume (tunic and trousers) and suggests that the mosaic may represent the punishment of the prisoners captured during Caracalla's eastern campaigns in $216 .^{28}$ While agreeing with Dunbabin that this hypothesis seems

26 K.M. Coleman, 'Fatal charades: Roman executions staged as mythological enactments', Journal of Roman Studies 8o (1990), 44-73.

27 The mosaic may be dated to the 3 rd or 2 nd century: see Carucci 2007 , op. cit. (n. 1), 78, $165^{-166 .}$

28 As the name Filoserapis is an epithet of Caracalla, Picard suggests that the villa-owner 


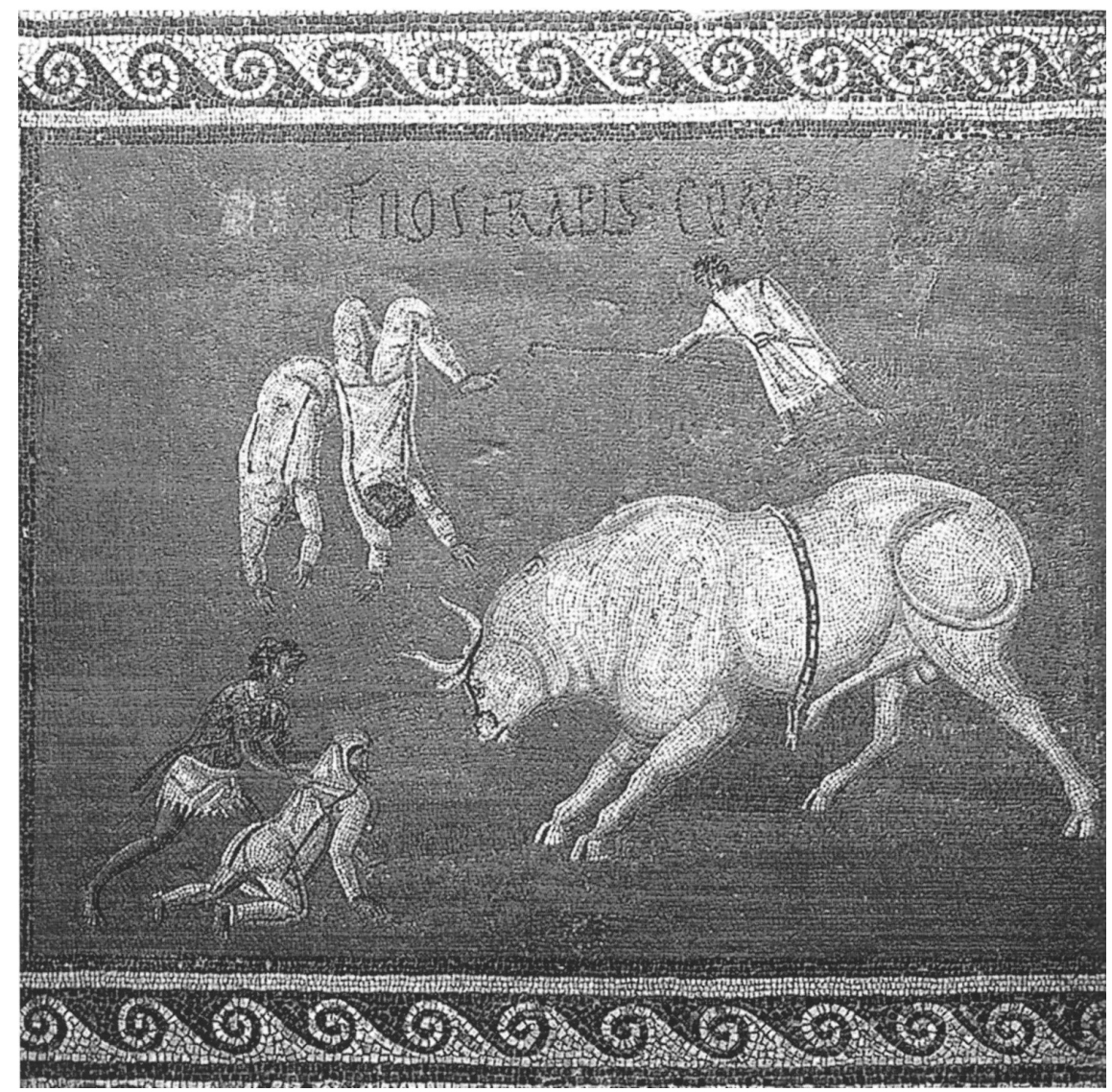

FIGURE 12.4 Silin, Villa du Taureau, mosaic of scene with bull tossing victims

too speculative, ${ }^{29}$ I suggest that the costume served to highlight the status of the criminals as foreigners who do not participate to the workings of the Roman social system. The victims' costume may indicate also an execution staged in the guise of mythological enactments, in which the criminals were dressed up and suffered the punishment that was proper to the plot. The depiction of a large white bull reminds us of the 'union' between Pasiphae and the bull that Martial states was truly enacted in the amphitheatre during the games cele-

used this epithet to show off his devotion to the emperor (G.Ch. Picard, 'La villa du taureau à Silin (Tripolitaine)' $C R A I$ (1985), 227-241). Filoserapis may be also the name of who organised the show.

29 K.M.D. Dunbabin, Mosaics of the Greek and Roman World (Cambridge 1999), 124 note 57. 
brating Titus' dedication of the Flavian Amphitheatre in 8 o C.E. ${ }^{30}$ With their two-way traffic between fiction and reality, the fatal charades highlight the theatrical character of the show of death, in which the convicted criminal played the main role on the central stage.

However, the description of the summa supplicia as a trivial form of drama staged merely for the entertainment of the audience does not capture the complex dynamics of the spectacular killing. In the Roman shows, the audience was not a group of passive spectators to be entertained: for the show to be performed, spectators had to play their role, too. Like the chorus of the ancient Greek tragedy, the audience in the arena participated in the fatal action with their comments, their applause, ${ }^{31}$ and their appeal for justice. ${ }^{32}$ In the drama of death, audience and convicted criminal were the two main characters each playing a specific role: the embodiment of the 'Normal' as just and good the former and the visual symbol of the Other as threatening and abnormal the latter.

The performance of their role was supported by the visual dynamics that the structural arrangement of the amphitheatre contributed to enact. From the upper rows the audience could cast their punitive gaze over the condemned on the lower stage: the power of the spectators' gaze turned the criminals into an object to be disposed of. The intentionally degrading and humiliating executions performed in full view before the massed audience served to strengthen the social distance between spectators and criminals and remove any possibility of empathy or pity on the part of the audience. The physical and emotional detachment of the spectators watching the blood spectacle is visualised in the depiction of the onlookers in the Thelepte mosaic as physically and emotionally removed from the central scene of venatio. Though the mosaic illustrates the killing of a lion and the executions of criminals was a different kind of visual experience, perhaps ancient Roman spectators viewed the violent and bloody executions of the criminals with the same kind of detachment, because criminals were merely objects to be disposed of. ${ }^{33}$

$30 \quad$ Mart. Lib. Spect. 5 .

31 On the applause in the theatre as an active instrument of participation, see H.N. Parker, 'The observed of all observers: spectacle, applause, and cultural poetics in the Roman theatre audience', in Bergmann and Kondoleon 1999, op. cit. (n. 9), 163-179.

For the use of the shows by the crowd as a form of communication with the emperor, see T.W. Africa, 'Urban violence in imperial Rome', The Journal of Interdisciplinary History 2:1 (1971), 3-21.

33 For a discussion of violence as part of the ordinary experience, see G.G. Fagan, 'Violence in Roman social relations', in M. Peachin (ed.), The Oxford Handbook of Social Relations in the Roman World (Oxford 2011), 467-495; M. Carucci, forthcoming, 'Domestic violence in 
However, the dynamics of the audience's emotional responses at play during the shows were more complex than what the artistic evidence seems to suggest. Though the Romans have left us very little comment on the effects of their shows upon the spectators, some textual passages show that the spectators were actively engaged with the suppliers of their entertainment. ${ }^{34}$ Ancient written record of the public's reactions to the games, though mostly focusing on gladiatorial combats, shows that watching the deadly games in the arena was a powerfully visual experience that was difficult to resist with emotional detachment, as the onlookers portrayed in the Thelepte mosaic may suggest.

The emotional engagement of the spectators as revealed through the physicality of their vocal expression across the social strata was a complimentary part of the shows, since it increased sensations of solidarity. For witnessing the staged executions of criminals in their role as dangerous outsiders of the social order enhanced the value of conformity and the spectators' solidarity in the face of threats to the established order. The play of justice in the arena required the audience members to be drawn in the act and contribute actively through their physical presence in the allocated seats, their vocal expression, their emotional engagement, and ultimately their acceptance of the imperial ideology.

This still leaves some questions: why did killing of wrongdoers have to be so spectacular? Why did it have to be staged in public areas and times dedicated to entertainment? Why did the Romans go so far in making a spectacle out of these punishments?

\section{Conclusion: Visualising and Publicising Justice}

As a Mediterranean community whose members place a high value on visibility and interaction in public spaces, Roman society was fundamentally public. Here, every individual could exercise what Foucault calls the "disciplinary gaze"35 on his fellows in a mutual action of watching and being watched. This reciprocity of the gaze had a double advantage for the community and the individual. On the one hand, the individual's act of watching over the behaviour of

Roman imperial society: giving abused women a voice', in M.C. Pimentel and N. Simões Rodrigues (eds.), Violence in the Ancient and Medieval Worlds (in press, 2018), 57-73.

34 See, for instance, St Augustine's description of his young friend and countryman Alypius' reaction to the gladiatorial combat (Confessions, 6.8). For more references, see M. Wistrand, Entertainment and Violence in Ancient Rome: the Attitudes of Roman Writers of the First Century A.D. (Göteborg 1992).

35 M. Foucault, Discipline and Punish. The Birth of Prison, trans. Alan Sheridan (New York 1977). 
his fellows guaranteed the reproduction of forms of behaviour and norms on which the traditional order of the community was based. On the other hand, being the object of the community's gaze was for the individual a means by which to prove the standards of his morality and hence his right of membership to that community. ${ }^{36}$ This right was irremediably lost when individuals disrupted the traditional order with their criminal offences or threatened the security of the state as enemies or rebels. Those individuals ought to be punished for their crimes ${ }^{37}$ in a variety of modes each fulfilling specific purposes, such as correction, ${ }^{38}$ retribution, ${ }^{39}$ and deterrence. ${ }^{40}$ However, the ultimate aim of every form of punishment was the protection and reinforcement of social harmony, order, and security of the whole community. In order to communicate this message in the most effective way, the various modalities of punishment needed to be publicised and witnessed. As discussed above, in the dual penal system of Roman law, whereby penalties had to be correlated with the crime and status of the offender, the most aggravated forms of punishment were exile and suicide for the honestiores and public executions for the humiliores. Though exile and suicide may appear as more privileged alternatives to ultimate penalties, I argue that exilium, political suicide, and summa supplicia functioned equally as visual modalities in the enactment of justice. The punishment of an elite member through his physical removal from the community, either in the form of exile or forced suicide, was visualised in his physical absence and in the removal of anything he could be remembered by (damnatio memoriae). Similarly, executions of low-status criminals were staged in highly public venues as a visual sign of imperial justice for the whole community to witness. Regardless of the social status of the offender and the type of penalties, punishments of the wrong-doers ought to be visible and public for

36 Even emperors ought to be visible for communicating and reinforcing their power: see O. Hekster, 'Captured in the gaze of power, visibility, games and Roman imperial representation', in O. Hekster and R. Fowler (eds.), Imaginary Kings: Royal Images in the Ancient Near East, Greece, and Rome (Munich 2005), 157-176.

37 Seneca (De Ira 2.2.4) accepts the violent execution of criminals during the games of the amphitheatre as unquestionably just. In his report on how Nero blamed the Christians for the fire at Rome in 64 C.E. and ordered their public execution, Tacitus describes the killing of the Christians as just and legitimate, though it could not meet with general approval because their execution did not seem to bring any public utility (Ann. 15.44.5). For a discussion of Roman writers' attitudes to violent entertainment see Wistrand 1992, op. cit. (n. 34).

38 Sen. Clem. 1.22.1; Gell. N.A. 7.14.3.

39 Gell. $N \cdot A \cdot 7 \cdot 14 \cdot 3$.

40 Gell. N.A. 7.14.4; Sen. Clem. 1.20.1; Quint. Decl. Mai. 274.13. For a full discussion of the penal aims in Roman juridical system, see Coleman 1990, op. cit. (n. 26), 44-49. 
the community to approve, and hence to reinforce the importance of the social good to which the members of the community were requested to contribute. In a society where the individual had strong obligations to the community and most actions were subject to public inspection, staged executions in the hugely attended shows of the amphitheatre communicated a powerful message: whoever endangers the Empire's moral stability with his heinous crimes is subject to moral evaluation, degradation, and punishment in front of the whole community. Convicted criminals were branded as infames ('without reputation'), a legal stigma attached to anyone who was deemed not trustworthy by society, such as individuals performing in public (actors, gladiators, and prostitutes), ${ }^{41}$ procurers, and soldiers dishonourably dismissed. ${ }^{42}$

In this context, criminal justice was a spectaculum, that is, a sight, an event or performance, which was enacted mainly to be seen and evaluated through the standards of public morality, a visual event created by the interaction between viewers and viewed. The audience was invited to see the criminal, the excruciating pain that his body's reactions and facial expressions made evident, and his physical and moral isolation, and made sense of this visual experience as a source of information about the values on which the community was based: justice, social order, conformity, and high moral standards.

The visually accessible execution affirmed the heinous character of the crimes in the body of the wrong-doers to be executed and hence justified justice. If the crime attacked justice and the moral values on which the very existence of the Empire was based, justice attacked the criminals to reinforce the authority of the law. ${ }^{43}$ The drama of death in the arena amplified this message by means of an apparent paradox in which both criminals and spectators became entangled. For the condition of the criminals on stage is somewhat

41 C. Edwards, 'Unspeakable professions: public performance and prostitution in Ancient Rome', in J.P. Hallett and M.B. Skinner (eds.), Roman Sexualities (Princeton 1997), 66-95.

42 Those who were legally and morally branded as disgraceful were denied a number of legal rights, e.g. they could not witness wills or other legal transactions; they could not appeal (Paul. Sent. 5.26) or make accusations against others (Dig. 48.2.4); they could not marry freeborn Romans (Ulpian, Frag. 13). For a discussion of infamia, see Edwards 1997, op. cit. (n. 41), 69-76.

43 The writers of the elite class judged severely those emperors that threw spectators into the shows or threatened them to be 'turned from spectator into spectacle' (Plin. Pan. 33): see, for example, Suet. Calig. 35.3; Dio, 59.10.3-4; Suet. Dom. 10 When the emperor threw spectators into the shows, the people were denied the opportunity to affirm their cohesiveness and superiority over the convicted criminals. Any crossing of boundary that the emperor permitted between the empowered spectators and the powerless performers was seen as a threat to social order and justice and led to question the legitimate power of the emperor himself. 
paradoxical: with their crimes they threatened the social order and security of the Empire and were therefore the enemies of the society as a whole; as infames, they had no place in the social and political hierarchy; however, they participated in a punishment that involved the whole society. The spectators, too, found themselves caught into this paradox through their role in the play: as the auxiliary of justice in the punishment of criminals, the socially variegated mass of anonymous spectators participated into the process of bestowing justice. Punishing criminals was an act of performance staged for reaffirming the specific values, behaviours, and cultural practices of Roman society.

In the arena, death becomes a spectacle on a grand scale, a form of entertainment with striking effects, an event with a strong visual impact. Yet, the killing of criminals in public venues was a performance inside the rituals of justice, which makes public executions distinctly Roman. The excessively violent death of the wrong-doers within the splendid apparatus of the shows in the amphitheatre was a means by which to visualise and reinforce the notion of imperial justice. Spectacular killing served as a very important occasion for articulating in a highly visible and public manner the hierarchical structure of the social order, the importance of the membership in the just and legitimate group, and the power of the law.

Played out in the arena and before the collective gaze, the drama of death was a form of spectacle communicating powerful messages: the significance of the social order, the authority of the spectators, the force of the communitas, and the legitimacy of the imperial power. This form of spectacle was performed inside the rituals of justice to be intended not as an abstract concept for imperial propaganda and philosophical discussions. Roman justice was rather a sign to visualise, a value to publicise, a performance that the whole community including the convicted criminals was required to play. As a collective performance, the drama of death in the arena was a spectacle of justice. 